ROCZNIKI NAUK SPOŁECZNYCH

Tom 13(49), numer 3 - 2021

DOI: https://doi.org/10.18290/rns21493.8

KATARZYNA KOSOWSKA

\title{
BEZPIECZEŃSTWO EKONOMICZNE REPUBLIKI BIAŁORUŚ W DOBIE KRYZYSU POLITYCZNO-GOSPODARCZEGO LAT 2020-POŁOWA 2021
}

\section{WPROWADZENIE}

Po rozpadzie ZSRR w grudniu 1991 roku, Republika Białoruś podjęła reformy mające na celu decentralizację władzy oraz urynkowienie gospodarki i zbliżenie z Zachodem, zwłaszcza z Unią Europejską, przy jednoczesnym utrzymywaniu bliskich relacji z Rosją. Reformy tego okresu - prywatyzacja przedsiębiorstw państwowych, uwolnienie cen, decentralizacja systemu zarządzania gospodarką, budowa korzystnego klimatu inwestycyjnego - charakteryzowały się ostrożnością i niezdecydowaniem (Kosiedowski, 2013, s. 230). Po uchwaleniu konstytucji w 1994 roku oraz wyborze na prezydenta państwa Aleksandra Łukaszenki sytuacja polityczno-gospodarcza Białorusi zaczęła się zmieniać. Kompetencje prezydenta uległy znacznemu poszerzeniu po zmianach wprowadzonych do konstytucji w wyniku ogólnokrajowych referendów z lat 1995, 1996 i 2004 (Kosiedowski, 2013, s. 230). W polityce gospodarczej nastąpił wówczas powrót do podporządkowania gospodarki władzy politycznej. Z kolei polityka zagraniczna Republiki Białoruś po 2000 roku zdominowana została przez pojęcie wielowektorowości, rozumiane jako ,utrzymywanie strategicznych relacji z Rosją, przy jednoczesnym zaktywizowaniu stosunków z Zachodem i innymi partnerami, w tym krajami Ruchu Państw Niezaangażowanych" (Czachor, 2011, s. 55). Dzięki swemu położeniu w Europie Wschodniej Białoruś stanowi naturalny pomost łączący Unię Europejską z krajami Wspólnoty Państw Niepodległych oraz pełni istotne znaczenie jako państwo tranzytowe w ramach połączeń transportowych Chiny-Unia Europejska. Populacja republiki

Dr KATARZYNA KoSOwSKA - adiunkt w Instytucie Rosji i Europy Wschodniej, Uniwersytet Jagielloński, Wydział Studiów Międzynarodowych i Politycznych; adres do korespondencji: ul. Władysława Reymonta 4, 30-059 Kraków; e-mail: katarzyna.1.kosowska@uj.edu.pl; ORCID: https://orcid.org/0000-0003-1998-3812. 
według stanu na 2021 roku wyniosła 9,4 mln, PKB - 60,1 mld USD, zaś stopa bezrobocia - 5,3\% (World Bank, 2021).

Trzecią dekadę XXI wieku Republika Białoruś rozpoczyna z licznymi problemami - pandemią Covid-19, niestabilną sytuacją społeczno-polityczną, zerwaniem dialogu z otoczeniem międzynarodowym oraz sankcjami Zachodu. Wszystkie wymienione czynniki spowodowały wiele zawirowań w białoruskiej gospodarce. W niniejszym artykule postawiona zostaje teza, zgodnie z którą w okresie ostatnich niespełna dwóch lat (2020-połowa 2021) obserwuje się wyraźne obniżenie poziomu bezpieczeństwa ekonomicznego Białorusi. Do głównych przyczyn takiej sytuacji należy zaliczyć dysfunkcjonalny model gospodarki, redukcję rosyjskich subsydiów energetycznych, skutki pandemii Covid-19 oraz masowe protesty i walkę z opozycjonistami po sfałszowanych wyborach prezydenckich 2020 roku, czego konsekwencją były sankcje Zachodu.

W Polsce powstało wiele analiz dotyczących sytuacji polityczno-gospodarczej Republiki Białoruś po sierpniu 2020 roku, wśród nich ekspertyzy oraz komentarze wydarzeń Ośrodka Studiów Wschodnich (Kłysiński, 2020, 2021) oraz Polskiego Instytutu Spraw Międzynarodowych (Dyner, 2020, 2021). Również analizy białoruskich badaczy z początku 2021 roku wskazują na słabszą kondycję krajowej gospodarki (Mozhejko, 2021, s. 44-53). Niniejszy artykuł stanowi uzupełnienie dotychczasowych badań nad bezpieczeństwem ekonomicznym Republiki Białoruś w badanym okresie czasu. W charakterze materiałów źródłowych wykorzystane zostaną dane pochodzące z białoruskiej bazy Bielstatu, Narodowego Banku Republiki Białoruskiej, Banku Światowego, Międzynarodowego Funduszu Walutowego oraz międzynarodowych agencji ratingowych.

\section{BEZPIECZEŃSTWO EKONOMICZNE - DEFINICJE}

Bezpieczeństwo oraz jego nieodzowna składowa, bezpieczeństwo ekonomiczne, zaliczane jest do podstawowych potrzeb każdego człowieka i społeczeństwa. W hierarchii potrzeb Masłowa znajduje się ono na drugim, pod względem ważności miejscu, po potrzebach fizjologicznych (Tambovcev, 1995). Choć pojęciem bezpieczeństwa ekonomicznego posługujemy się często, zarówno w analizach teoretycznych, jak i w działalności praktycznej, to określenie jego istoty jest problemem złożonym, gdyż pojęcie to jest wielowymiarowe i wciąż ewoluuje. Podejście do bezpieczeństwa ekonomicznego różni się w zależności od dyscypliny, w której stosuje się tę koncepcję: teoretyczną analizę bezpieczeństwa 
ekonomicznego można zaleźć zarówno w naukach ekonomicznych, naukach politycznych, a także w naukach o bezpieczeństwie.

Bezpieczeństwo ekonomiczne w ujęciu węższym jest czasem ujmowane jako triada komponentów: surowcowego, żywnościowego i finansowego (Szubrycht, 2006, s. 91; Buzan, 1991, s. 19), dzięki którym możliwy jest harmonijny rozwój gospodarki oraz zapewnienie odpowiedniego życia obywateli. W kontekście definiowania bezpieczeństwa ekonomicznego zauważyć można nurt przyjmowania dualnego podziału, w którym rozpatruje się płaszczyznę społeczno-gospodarczą oraz ekonomiczno-obronną (Frejtag-Mika i in., 1996, s. 10; Senchagov, 2002, s. 72). Badacze traktujący zjawisko bezpieczeństwa ekonomicznego w ujęciu szerszym rozpatrują je jako względnie zrównoważony endo- i egzogennie stan funkcjonowania gospodarki narodowej, w którym występujące ryzyko zaburzeń utrzymywane jest w wyznaczonych i akceptowalnych normach (Raczkowski, 2012, s. 81). Procesy globalizacji wpłynęły na zmianę podejścia do kwestii bezpieczeństwa ekonomicznego. Globalizacja w kontekście gospodarczym zwróciła uwagę badaczy na problematykę podatności poszczególnych gospodarek na głębokie recesje, kryzysy gospodarcze spowodowane liberalizacją gospodarki światowej (Nesadurai, 2005). Gospodarka stała się również środkiem oddziaływania jednych państw na inne. Wzrost znaczenia kwestii ekonomicznych dla bezpieczeństwa oznacza również zmianę postrzegania przestrzeni, która do tej pory była ujmowana w sensie geograficznym, a dziś jest ujmowana w sensie ekonomicznym. Oznacza to przejście od geopolityki do geoekonomii (Lorot, 2009).

Zagadnienie bezpieczeństwa ekonomicznego w Republice Białoruś po raz pierwszy zostało poruszone w 1995 roku w Koncepcji Bezpieczeństwa Narodowego Republiki Białoruś, która odzwierciedlała problemy udziału kraju w procesach globalizacji i włączenia go do światowego systemu gospodarczego. W ustawodawstwie białoruskim bezpieczeństwo ekonomiczne jest rozumiane jako stan gospodarki, w którym zagwarantowana jest ochrona interesów narodowych państwa przed zagrożeniami wewnętrznymi i zewnętrznymi (Koncepcija nacional'noj, 2010). W pracach białoruskich badaczy (Mjasnikovich, 2006, s. 300; Nikitenko, 2009, s. 394) bezpieczeństwo ekonomiczne jest definiowane jako zespół środków nakierowanych na ochronę narodowych interesów systemu gospodarczego, które mają działanie regulacyjne w celu przeciwdziałania zagrożeniom wewnętrznym i zewnętrznym, zapewniają ochronę i konkurencyjność oraz stabilność finansową i społeczno-gospodarczą.

Przyjmując jako kryterium źródło czynnika kształtującego bezpieczeństwo ekonomiczne, w niniejszym artykule nacisk położony zostanie na uwarunkowania 
wewnętrzne i zewnętrzne bezpieczeństwa. Do czynników wewnętrznych zaliczać będziemy charakter systemu gospodarczego, strukturę gospodarki, sytuację finansową i budżetową oraz koniunkturę gospodarczą. Z kolei pod pojęciem czynników zewnętrznych rozumieć będziemy procesy zachodzące w gospodarce światowej, funkcjonowanie państwa w międzynarodowych organizacjach ekonomicznych i finansowych oraz zakres swobody wymiany międzynarodowej (Kostecki, 2016).

\section{CHARAKTER SYSTEMU GOSPODARCZEGO BIAŁORUSI}

W czasach rządów Aleksandra Łukaszenki w Republice Białoruś ukształtował się specyficzny, hybrydowy model gospodarczy, który określony został jako „społecznie zorientowana gospodarka rynkowa” (Nacional'naja strategija, 2004). Model ten zdefiniowany został w "Narodowej Strategii Zrównoważonego rozwoju społeczno-gospodarczego Republiki Białoruś do 2020 roku” jako „efektywna gospodarka z zaawansowaną przedsiębiorczością i infrastrukturą rynkową, skuteczną regulacją państwową, zachęcającą przedsiębiorców do rozwoju i poprawy jakości produkcji, a pracowników do bardziej wydajnej pracy" (Nacional'naja strategija, 2004). W rzeczywistości model gospodarczy Białorusi bazował na następujących filarach: utrzymywaniu dużego udziału państwa we wszystkich głównych sektorach gospodarki, centralizacji zarządzania gospodarką, utrzymywaniu wysokiego zatrudnienia dzięki systemowi zamówień rządowych i całkowitemu zakazowi zwolnień pracowników; subsydiowaniu przez państwo nierentownych przedsiębiorstw państwowych, wyhamowaniu procesu prywatyzacji. Obranie takiej drogi rozwoju gospodarczego wynikało z negatywnego stosunku prezydenta Łukaszenki do gospodarki wolnorynkowej, utożsamianej z „,anarchią”, „zamieszaniem” czy „,chaosem”.

Według danych Bielstatu w 2019 roku sektor państwowy w gospodarce białoruskiej reprezentowany był przez ponad 17,5 tys. podmiotów gospodarczych, 15 tys. instytucji oraz około 1,6 tys. firm z udziałem państwa (Bielstat, 2019). Według różnych źródeł dziś około 60-70\% produkcji przemysłowej wytwarzanej jest przez wymagający restrukturyzacji sektor państwowy. W 2018 roku MFW wskazywał na Republikę Białoruś jako kraj europejski z największą kontrolą państwa w gospodarce. Na przedsiębiorstwa będące własnością państwa lub przez nie kontrolowane przypada około połowy całkowitego zatrudnienia (MFW, 2018, s. 4). Granica między państwem a gospodarką w przypadku Białorusi jest bardzo płynna: „W naszym kraju mówimy «gospodarka» - a mamy 
na myśli «państwo». Mówimy «państwo» - a mamy na myśli «gospodarkę»", stwierdza dyrektor Centrum Badawczego MISES, Jarosław Romanczuk (Romanczuk, 2017). Własność państwowa dominuje w rolnictwie - 91\% ziem uprawnych na Białorusi należy do kołchozów, agroholdingów i innych organizacji pośrednio podległych kontroli państwowej, 7,1\% - do tzw. przyzakładowych działek, zaś jedynie $2,1 \%$ przypada na farmy prywatne. Oficjalne białoruskie statystyki jednoznacznie wskazują na znacznie niższą efektywność działania kołchozów w stosunku do farm prywatnych: w 2018 roku średnia rentowność sprzedaży kołchozów wyniosła $3,7 \%$, podczas gdy w przypadku gospodarstw prywatnych - 22,7\% (Sel'skoe hozjajstvo, 2019). W 2020 roku w gospodarce białoruskiej ogółem 16,4\% firm państwowych było nierentowanych wobec 14,7\% w 2019 roku (Bielstat, 2020). Niewłaściwie zarządzane przedsiębiorstwa mogą jednak liczyć na wsparcie ze strony państwa. W 2018 roku pomoc finansową na kwotę 2 mld rubli otrzymało 1856 firm państwowych. W 2019 roku zadłużenie sektora państwowego wynosiło 2,46 mld USD (Bielstat, 2020).

Nierentowne firmy sektora państwowego Białorusi w latach 2010-2020 (\%)

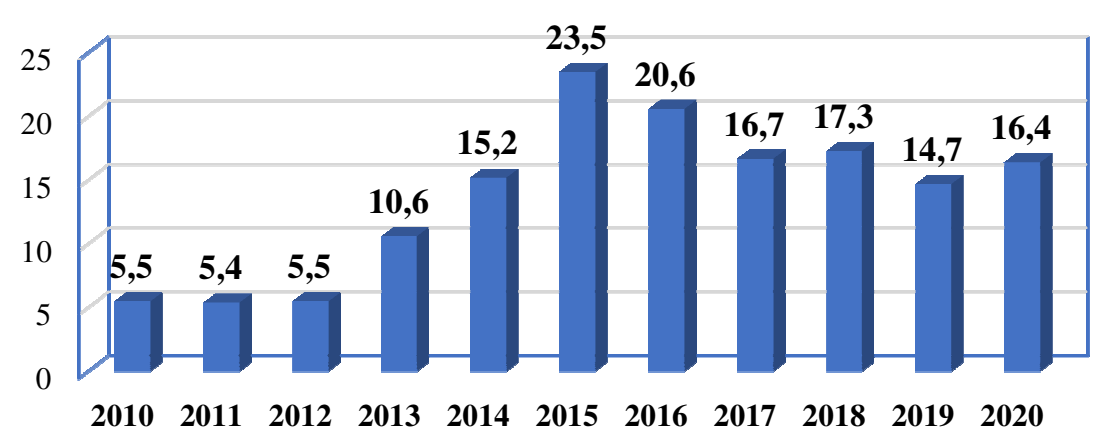

Wykres 1. Nierentowne firmy sektora państwowego Białorusi w latach 2010-2020 (w \%). Źródto: Bielstat (2020).

Rozległa własność państwa i kontrola rządowa, zwłaszcza w rolnictwie i przemyśle, poważnie ogranicza inwestycje i działalność finansową. W 2019 roku Republika Białoruś odnotowała spadek z 37 miejsca na 49 miejsce (na 190 państw) w rankingu łatwości prowadzenia biznesu Doing Business przygotowanym przez 
Bank Światowy. Białoruś została znokautowana przez prawie wszystkich członków Euroazjatyckiej Unii Gospodarczej (Kazachstan - 25 miejsce, Rosja - 28, Armenia - 47, Kirgistan - 80). Najmniej punktów wschodniosłowiańska republika uzyskała w kategorii dostępu do kredytów, ochrony inwestorów oraz procedur związanych z zakończeniem działalności gospodarczej (Doing Business, 2020).

W pierwszej dekadzie XXI wieku model gospodarczy Białorusi wzbogacony został przez dynamicznie rozwijającą branżę IT, sektor priorytetowy, który w ostatnich latach mógł liczyć na liczne ulgi oraz przywileje podatkowe za sprawą wsparcia ze strony prezydenta Łukaszenki. W 2019 roku sektor IT wypracował $6,5 \%$ PKB, czyli tyle, co rolnictwo czy transport. Analitycy zakładali dalszy wzrost IT w gospodarce Białorusi do 10\% PKB w latach 2022-2023 (Jushkevich, 2019).

\section{EKONOMICZNE ŁAŃCUCHY ZALEŻNOŚCI REPUBLIKI BIAŁORUŚ OD FEDERACJI ROSYJSKIEJ}

Opisany wyżej, archaiczny model gospodarki przez wszystkie lata istnienia Republiki Białoruś był w stanie funkcjonować dzięki ogromnemu wsparciu ze strony Federacji Rosyjskiej, które miało trzy wymiary: kredytowy, inwestycyjny oraz energetyczny. W ciągu ostatnich lat Białoruś była największym beneficjentem rosyjskich kredytów - na koniec 2019 roku jej zadłużenie względem Rosji wyniosło 8,1 mld USD, czyli 35\% z łącznej puli 22,9 mld USD rosyjskich kredytów (Vedomosti, 2020). Republika Białoruś mogła liczyć na wsparcie kredytowe z Euroazjatyckiego Funduszu Stabilizacji i Rozwoju, międzynarodowej organizacji finansowej, której budżet w większości finansowany jest przez Rosję. Na Federację Rosyjską przypada dziś ponad 60\% całkowitego zewnętrznego długu publicznego Białorusi. W 2011 roku Rosja udzieliła Białorusi kredytu wielkości 10 mld USD na budowę elektrowni jądrowej w Ostrowcu. Zgodnie z zawartym porozumieniem rosyjskie pożyczki miały pokryć 90\% kosztów budowy, zaś za sfinansowanie pozostałych 10\% odpowiedzialna była strona białoruska (Soglashenie, 2011). Pierwszy z dwóch bloków elektrowni, budowanej przez rosyjską spółkę Rosatom, miał zostać uruchomiony w 2018 roku, zaś drugi - w 2019. Ostatecznie otwarcie pierwszego bloku elektrowni odbyło się w listopadzie 2020 roku. Decyzja o budowie elektrowni w Ostrowcu została podjęta w związku z planami eksportu energii elektrycznej na rynki Litwy, Łotwy i Polski. W obecnej sytuacji politycznej inwestycja ta jest zupełnie nieopłacalna, gdyż władze białoruskie są zmuszone 
do sprzedaży energii poniżej kosztów produkcji na rynek rosyjski oraz spłaty kredytu rozłożonego na 15 lat, który jest największym obciążeniem finansowym w historii niepodległej Białorusi (Kłysiński i in., 2020).

Federacja Rosyjska pozostawała także niekwestionowanym liderem pod względem bezpośrednich inwestycji zagranicznych (BIZ) na Białorusi. W ciągu ostatnich 30 lat ponad połowa wszystkich BIZ na Białorusi przypadała na inwestorów z Rosji. W latach 2010-2018 udział rosyjskich BIZ w białoruskiej gospodarce wahał się w przedziale 55-60\%, jednakże w okresie 2019-2020 nastąpiło skurczenie się wskaźnika do około 32\% (Bank Narodowy Białorusi, 2020).

Największy pakiet wsparcia Republika Białoruś otrzymała od Federacji Rosyjskiej w formie subsydiów energetycznych. Szacuje się, że w latach 2012-2019 wyniósł on około 45 mld USD. W okresie wysokich cen ropy rosyjskie subsydia energetyczne sięgały 17\% (2012) białoruskiego PKB (Titova, 2020). Rosyjskie dotacje dla Białorusi można podzielić na trzy grupy; pierwszą z nich stanowiły preferencyjne ceny gazu ziemnego. W 2012 roku Białoruś płaciła Gazpromowi 168,4 USD za $1000 \mathrm{~m}^{3}$ gazu ziemnego, podczas gdy odbiorcy z UE - 368,8 USD. Z tego tytułu rosyjskie subsydia gazowe dla Republiki Białoruś w latach 2012-2019 sięgnęły 17,4 mld USD. Drugą grupę rosyjskich dotacji stanowią zerowe cła eksportowe na ropę, oceniane w badanym okresie czasu na 24,9 mld USD. Ostatnia, trzecia grupa to bezcłowy import produktów naftowych z Rosji, który przyniósł białoruskiej gospodarce 2,7 mld USD (Titova, 2020). Preferencyjne ceny ropy naftowej importowanej z Rosji pozwalały na pomyślne funkcjonowanie dwóch wielkich białoruskich rafinerii - w Mozyrzu i Nowopołocku, największych płatników białoruskiego budżetu. Białoruś importowała ropę naftową według stałych stawek uzgodnionych z Rosją, by następnie sprzedawać swoje produkty naftowe po cenach światowych na rynkach europejskich. Eksport produkcji obu rafinerii w znacznym stopniu wpływa na położenie całej białoruskiej gospodarki, stanowiąc nawet 60\% nominalnej wartości PKB (Sektor energetyczny, 2015). Z kolei dzięki niskim cenom gazu ziemnego sprowadzanego z Rosji Białorusini przez lata byli w stanie utrzymywać swój przestarzały przemysł. W zamian za utrzymywanie niskich cen gazu ziemnego i ropy naftowej władze białoruskie oddawały Rosji swe strategiczne aktywna energetyczne - kontrolę nad operatorem białoruskich gazociągów Bieltransgaz czy udziały w rafinerii Mozyr (Gromadzki, Konończuk, 2007, s. 28). Kapitał rosyjski w białoruskiej energetyce reprezentowany jest przez takich gigantów, jak Gazprom, Rosneft, Rosatom. Dziś republika pozostaje w całkowitej zależności od dostaw gazu ziemnego z Rosji, stanowiącego ponad $60 \%$ jej miksu energetycznego. Wskazać możemy 
również na zależność handlową obu państw - Rosja jest głównym rynkiem zbytu dla towarów białoruskiej produkcji.

\section{RELACJE GOSPODARCZE CHIŃSKIEJ REPUBLIKI LUDOWEJ Z REPUBLIKĄ BIAEORUŚ}

Pogłębiająca się zależność od Federacji Rosyjskiej oraz skomplikowane stosunki z Zachodem wymusiły konieczność budowania relacji z krajami spoza Europy. W ramach prowadzonej przez Białoruś polityki wielowektorowości najważniejszym pozaeuropejskim kierunkiem stał się rozwój stosunków z Chinami, które dyplomacja białoruska zaczęła definiować jako ,partnera strategicznego”.

Celem Białorusi było zwiększenie pola manewru w polityce zagranicznej, pozyskanie środków finansowych na modernizację gospodarki w postaci kredytów oraz inwestycji, jak również wzrost białoruskiego eksportu do Chińskiej Republiki Ludowej. Szeroki dostęp do chińskiego rynku zbytu w zakresie produkcji spożywczej, samochodów ciężarowych czy maszyn rolniczych pozwoliłby Białorusi na częściowe zrównoważenie zależności gospodarczej od Rosji w tych obszarach. Oferta gospodarcza Chin skoncentrowana była również wokół parku przemysłowego Wielki Kamień pod Mińskiem, specjalnej strefy ekonomicznej powstałej w celu przyciągnięcia zagranicznych firm działających w obszarze nowoczesnych technologii (Dyner, 2018). Z kolei Chiny postrzegały Republikę Białoruś jako swoje centrum produkcyjne w obrębie Euroazjatyckiej Unii Gospodarczej oraz strategiczne państwo tranzytowe dla przewozów kolejowych Chiny-Unia Europejska (Jakóbowski, Kłysiński, 2021, s. 5).

Kolejne lata współpracy białorusko-chińskiej nie przyniosły jednak oczekiwanych przez prezydenta Łukaszenkę rezultatów: chińskie kredyty państwowe przekierowane zostały na projekty infrastrukturalne i budowę fabryk, których realizacja była oparta na technologii i sile roboczej z Chin. Obrót towarowy z Chińską Republiką Ludową w 2020 roku nie przekraczał 6\% wymiany handlowej Białorusi, zaś chińskie inwestycje zagraniczne pozostawały na poziomie poniżej 3\% (Jakóbowski, Kłysiński, 2021, s. 5-6). Współpraca gospodarcza z Chinami nie przełożyła się ponadto na modernizację przestarzałego białoruskiego przemysłu czy rozwój nowoczesnych gałęzi gospodarki. Również inwestycje chińskie w energetykę okazały się o wiele skromniejsze niż oczekiwania strony białoruskiej (Czwołek, 2014). Podsumowując, model współpracy białorusko-chińskiej przyniósł wielkie rozczarowanie prezydentowi Łukaszence. 


\section{BEZPIECZEŃSTWO EKONOMICZNE BIAŁORUSI \\ W LATACH 2020-POŁOWA 2021}

Szczodre dotacje ze strony Federacji Rosyjskiej pozwoliły gospodarce białoruskiej w pierwszych latach XXI stulecia wejść na drogę wzrostu gospodarczego bez przeprowadzania strukturalnych reform rynkowych. Jednakże przystąpienie Białorusi do Euroazjatyckiej Unii Gospodarczej w 2015 roku oraz domaganie się z tego tytułu niższych cen na dostawy gazu ziemnego z Rosji wywołało konflikt energetyczny na linii Moskwa-Mińsk, który z czasem przerodził się w głęboki kryzys i objął m.in. procedury kontroli granicznej, dostęp białoruskich produktów spożywczych do rosyjskiego rynku oraz kwestie dostępu Białorusi do rosyjskiej oferty kredytowej (Kardaś, Kłysiński, 2017). W dalszej kolejności Rosja uzależniła kontynuację wsparcia energetycznego od gotowości Białorusi do pogłębionej integracji w ramach Państwa Związkowego. Sprzeciw prezydenta Łukaszenki w tej kwestii skutkował redukcją rosyjskich subsydiów energetycznych. Kryzys gospodarczy, który rozpoczął się na Białorusi w pierwszym kwartale 2020 roku, spotęgowany został przez skutki pandemii Covid-19 oraz zerwanie dialogu polityczno-gospodarczego z Zachodem po sfałszowanych wyborach prezydenckich $\mathrm{w}$ sierpniu tego samego roku. W marcu 2020 roku wystąpiły pierwsze symptomy deprecjacji rubla, która radykalnie przyśpieszyła w drugiej połowie roku, zaraz po wyborach prezydenckich.

Tłumienie wystąpień opozycyjnych po nieuznanych przez Zachód wyborach prezydenckich spotkało się z ostrą krytyką otoczenia międzynarodowego, które nałożyło na Republikę Białoruś sankcje. Kolejne pakiety sankcji były nakładane przez UE oraz USA jesienią-zimą 2020 roku (w dużej mierze personalny charakter sankcji) oraz wiosną-latem 2021 roku (charakter sektorowy sankcji - objęły one sektor rafineryjny, petrochemiczny, nawozowy i bankowy). Zerwany dialog z Zachodem pozbawił Łukaszenkę możliwości dotychczasowego balansowania między UE a Rosją, zwłaszcza w obszarze gospodarczym. Zaś koszty pierwszego pakietu zachodnich sankcji to przede wszystkim spadek zaufania wśród inwestorów i kredytodawców zachodnich.

Po wydarzeniach z sierpnia 2020 roku nastąpił drastyczny spadek wiarygodności kredytowej Białorusi na rynkach międzynarodowych. We wrześniu i listopadzie 2020 roku nową ocenę wystawiły wschodniosłowiańskiej republice dwie spośród trzech najważniejszych światowych agencji ratingowych - S\&P oraz Fitch. Agencja Fitch utrzymała długoterminowy rating Białorusi na poziomie „B”, niemniej jednak obniżyła perspektywę ratingu ze „stabilnej” 
na „,negatywną”. Rewizja prognozy na „negatywną” odzwierciedla pogląd Fitch, że „,...] kryzys polityczny na Białorusi [...] zwiększył podatność na zagrożenia spowodowane stosunkowo niskimi międzynarodowymi rezerwami walutowymi i słabym sektorem bankowym. Nasilenie niepokojów politycznych mogłoby wywrzeć dodatkową presję na rezerwy międzynarodowe i doprowadzić do odpływu depozytów, zwiększając ryzyko dla stabilności makroekonomicznej i finansowej" (Fitch, 2020). Pozostałe dwie agencje - S\&P oraz Moody's - również obniżyły perspektywę ratingu Białorusi ze „stabilnej” na „negatywną”. S\&P zauważa, że sytuacja w gospodarce i niepewność polityczna doprowadziły na początku września 2020 roku do deprecjacji waluty krajowej o $20 \%$ w stosunku do dolara. Największe białoruskie banki - Belarusbank, Belagroprombank i Bank BelVEB - stanęły w obliczu ogromnych niespłaconych zobowiązań kredytowych. Rezerwy kapitałowe białoruskich banków zostały ocenione jako niskie według standardów międzynarodowych (S\&P, 2020).

Tabela 1. Zmiana ratingu kredytowego Republiki Białoruś w latach 2020/2021 przez agencje Fitch, S\&P oraz Moody's

\begin{tabular}{|l|c|c|c|}
\hline \multicolumn{1}{|c|}{ Agencja } & Rating & Outlook & Data \\
\hline Fitch & B- & negatywny & 13 listopada 2020 r. \\
\hline S\&P & B & negatywny & 11 września 2020 r. \\
\hline Moody's & B3 & negatywny & 1 października 2021 r. \\
\hline Fitch & B & stabilny & 26 stycznia 2018 r. \\
\hline S\&P & B & stabilny & 6 października 2017 r. \\
\hline Moody's & B3 & stabilny & 16 marca 2018 r. \\
\hline
\end{tabular}

Źródto: opracowanie własne na podstawie danych ze stron Fitch, S\&P oraz Moody’s.

W przypadku Białorusi spadek wiarygodności kredytowej przekłada się na ograniczony dostęp państwa do międzynarodowych instytucji finansowych i w konsekwencji brak możliwości refinansowania ogromnego zadłużenia zagranicznego państwa na rynkach zagranicznych, z wyjątkiem rosyjskiego.

Problem z pozyskiwaniem kredytów na rynkach międzynarodowych jest kluczowy ze względu na ogromne zadłużenie zewnętrzne Republiki Białoruś. Według danych Ministerstwa Finansów zadłużenie zewnętrzne Białorusi na dzień 1 stycznia 2021 roku wyniosło 18,6 mld USD, czyli o 8,4\% więcej niż przed rokiem. Obecnie zadłużenie zewnętrzne stanowi 30,9\% PKB Białorusi (MFRB, 2020). Dziś w kraju nie ma niezadłużonego sektora gospodarki. 
W styczniu 2021 roku zadłużenie białoruskich przedsiębiorstw pobiło rekord. Wzrost zobowiązań dużych i średnich przedsiębiorstw był najwyższy od pięciu lat: na 1 stycznia 2021 roku wyniósł 158,4 mld BYN. Zadłużenie przedsiębiorstw przekroczyło roczne PKB Białorusi. W 2020 roku zadłużenie białoruskich firm wzrosło o 19,3\%, czyli najszybciej w ciągu ostatnich 5 lat (Dolgi, 2021). Sytuację pogarsza fakt, że banki coraz częściej odmawiają firmom kredytowania.

Rosnąca niepewność polityczna i gospodarcza Republiki Białoruś, zagrożenie sankcjami ze strony Zachodu wpłynęły na spadek zaufania wśród inwestorów zagranicznych. Od czasów wyborów prezydenckich w połowie 2020 roku zaobserwować można wzmożone wycofywanie się kapitału zagranicznego z białoruskiego rynku (Zajac, 2021). Najwięcej szkód gospodarce może przynieść ucieczka z rynku firm branży IT, która rozpoczęła się niedługo po wydarzeniach sierpniowych. Największy pracodawca tego sektora na Białorusi - EPAM - podjął decyzję o otwarciu przedstawicielstwa na Litwie, choć wcześniej zatrudniał programistów białoruskich. Obok Litwy, firmy sektora IT przenoszą biznes również do Polski oraz na Ukrainę, gdzie mogą liczyć na bardziej przyjazny klimat inwestycyjny (Trusewicz, 2020). Masowy odpływ specjalistów sektora IT niewątpliwie przełoży się na zmniejszenie inwestycji w białoruskie firmy z tej dziedzinie, co z kolei zada mocny cios i tak już słabej gospodarce białoruskiej.

Dane Belstatu potwierdzają tendencję odpływu inwestycji zagranicznych z Białorusi. W 2020 roku wyniosły one 8,7 mld USD, czyli 13\% mniej niż w roku poprzednim. Bezpośrednie inwestycje zagraniczne (BIZ) sięgnęły 6 mld USD (69,2\% całości). Jest to najniższy odnotowany poziom inwestycji od 2016 roku. Federacja Rosyjska zachowała status głównego inwestora z udziałem sięgającym prawie 50\% (Bielstat - Inwestycje zagraniczne, 2021).

Tabela 2. Inwestycje zagraniczne w gospodarce Białorusi w latach 2015-2020 (mld USD)

\begin{tabular}{|l|c|c|c|c|c|c|}
\hline \multicolumn{1}{|c|}{ Rok } & 2015 & 2016 & 2017 & 2018 & 2019 & 2020 \\
\hline $\begin{array}{l}\text { Inwestycje } \\
\text { zagraniczne }\end{array}$ & 11,3 & 8,6 & 9,7 & 10,8 & 10,01 & 8,7 \\
\hline $\begin{array}{l}\text { W tym } \\
\text { inwestycje } \\
\text { bezpośrednie }\end{array}$ & 7,2 & 6,9 & 7,6 & 8,5 & 7,2 & 6,0 \\
\hline
\end{tabular}

Źródto: Bielstat - Inwestycje Zagraniczne (2021). 
Warto w tym miejscu zaznaczyć, iż „Projekt rozwoju społeczno-gospodarczego Republiki Białoruś na lata 2021-2025" pomija bezpośrednie inwestycje zagraniczne (BIZ) kapitału zachodniego, koncentruje się głównie wokół chińskich inwestycji zagranicznych (Osnovnye polozhenija, 2021). Jest raczej mało prawdopodobne, że Białoruś będzie w stanie przyciągnąć duże inwestycje z Chińskiej Republiki Ludowej, gdyż strona chińska zainteresowana jest głównie eksportem swoich towarów na Białoruś. Z drugiej strony, trudno oczekiwać, aby Rosja, pogrążona w swych własnych problemach gospodarczych, chciała i była w stanie wypełnić lukę inwestycyjną powstałą po odpływie zachodniego kapitału inwestycyjnego z Białorusi.

Można prognozować, iż 2021 rok przyniesie kolejne, jeszcze większe spadki poziomu inwestycji na Białorusi ze względu na rosnące ryzyko inwestycyjne. W tym kontekście warto również zwrócić uwagę na Indeks Wolności Gospodarczej (Index of Economic Freedom) wystawiony dla Białorusi w 2021 roku. Poziom wolności gospodarczej oceniony został na 61,0 punktów, czyli 0,7 punktu mniej niż rok wcześniej. Republika Białoruś zajęła 43 miejsce wśród 45 krajów regionu Europy, a jej ogólny wynik jest poniżej średniej regionalnej i światowej. W 2020 roku odnotowano spadek w zakresie: praw własności, skuteczności wymiaru sprawiedliwości, swobody prowadzenia biznesu oraz wolności handlu (The Heritage Foundation, 2021). Uzyskany przez Białoruś wynik na poziomie 61,0 punktów pozwala zaliczyć republikę do grupy państw „umiarkowanie wolnych" (60-69,9 pkt), jednakże oscyluje on wokół dolnej granicy tej grupy.

Negatywne tendencje zaobserwowano również w handlu zagranicznym. W 2020 roku obroty handlowe gospodarki białoruskiej wyniosły 60,7 mld USD, w tym na eksport przypadło 28,4 mld USD, na import - 32,3 mld USD. Tym samym eksport odnotował spadek o $11,8 \%$, zaś import - o 17,4\% w stosunku do roku poprzedniego (Itogi vneshnej torgovli, 2021). Spadek białoruskiego eksportu, spowodowany pandemią Covid-19 oraz pogłębiającym się kryzysem politycznym, wpłynął na powstanie deficytu budżetowego w okresie styczeń-luty 2020, pierwszego od ośmiu lat.

Redukcji zagranicznych inwestycji na Białorusi towarzyszy odpływ siły roboczej głównie do państw ościennych. W ciągu ostatnich dwóch lat liczba obywateli Republiki Białoruś mających zezwolenie na pobyt w Polsce wzrosła o około 50\% i przekroczyła poziom 30 tys. osób. Około 64\% z tej liczby stanowią osoby w przedziale 18-40 lat (Obywatele Białorusi w Polsce, 2021).

Głównym powodem emigracji Białorusinów jest niższy w stosunku do sąsiadów poziom dobrobytu obywateli. Białoruś sąsiaduje z pięcioma krajami - Rosją, Ukrainą, Polską, Litwą i Łotwą. Otwartość granic między państwami pozwala 
na porównanie poziomu życia obywateli i sukcesów gospodarczych osiąganych przez sąsiadów. To z kolei staje się ważnym czynnikiem skłaniającym ludzi do zmian. Powołując się na wskaźnik PKB per capita, możemy porównać poziom życia Białorusinów $\mathrm{z}$ ich najbliższym otoczeniem zagranicznym. PKB per capita Białorusi w 2020 roku odnotował 7,6\% spadek w stosunku do roku poprzedniego i wyniósł 6411 USD, co stanowi jedynie 32\% PKB per capita Litwy, $36 \%$ - Łotwy i $41 \%$ - Polski. Na tym tle gorszy od Białorusi wynik osiągnęła jedynie Ukraina. A zatem wszyscy sąsiedzi Republiki Białoruś (z wyjątkiem Ukrainy) cieszą się wyższym poziom dobrobytu.

PKB per capita w latach 2010-2020 (USD) w cenach bieżących

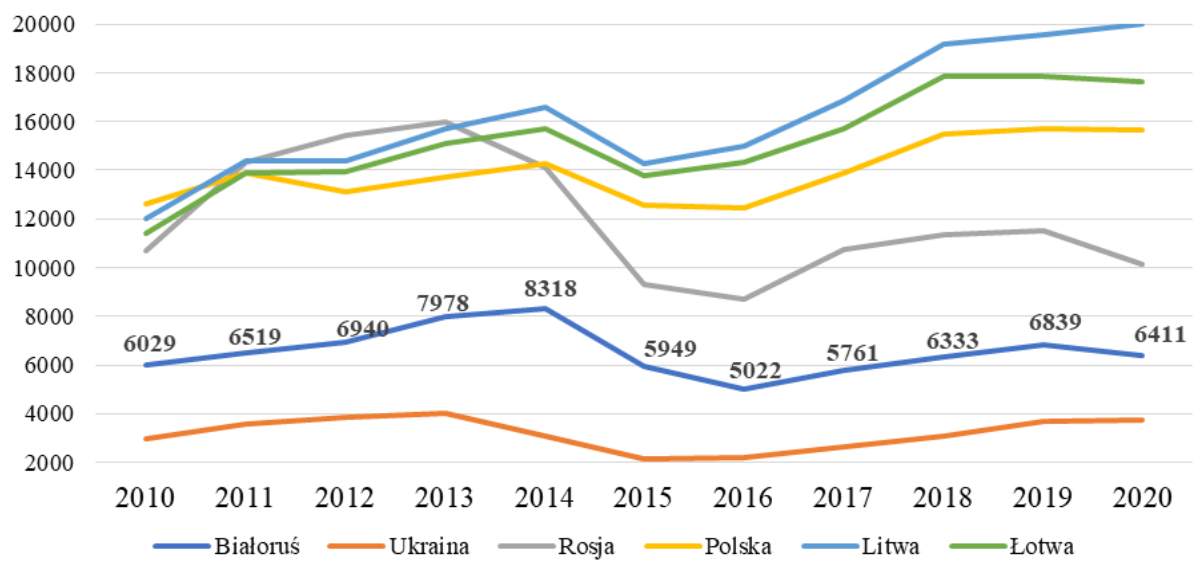

Wykres 2. PKB Białorusi i państw sąsiadujących w latach 2010-220 (UDS) w cenach bieżących.

Źródto: Opracowanie własne na podstawie danych Banku Światowego: https://data.worldbank.org/ indicator/NY.GDP.PCAP.CD?locations=BY [dostęp: 15.10.2021].

Sami Białorusini nie oceniają swojego poziomu życia wysoko. Według badań socjologicznych przeprowadzonych przez Centrum Badań i Analiz przy Administracji Prezydenta Republiki Białoruskiej, w 2018 roku ponad 1/4 respondentów (28\%) wskazała na deficyt dobrobytu materialnego, $2 \%$ ankietowanych stwierdziło, iż żyje poniżej progu ubóstwa, zaś zaledwie $0,5 \%$ badanych odniosło siebie do grupy bogatych (Respublika Belarus', 2018, s. 80). 
Według danych Komisji Europejskiej ponad 90\% Białorusinów pracuje na podstawie umów o pracę na czas określony (tzw. umowy śmieciowe), z czego $35 \%$ jest zawieranych na okres 3-5 lat, 31\% - od 1 do 3 lat i 30\% - na okres roku. Alternatywne formy zatrudnienia pracowników nie są praktykowane (Rezervy uzhestochenija, 2016). Zatem Białoruś nie stosuje systemu stałego zatrudniania pracowników, co sprawia, że pozostają oni całkowicie uzależnieni od pracodawców. Pracownik sektora państwowego nie ma prawa do zerwania umowy o pracę z własnej woli w przypadku chęci podjęcia nowej pracy. Zarobki $\mathrm{w}$ sektorze państwowym są niskie, na poziomie 500 USD miesięcznie (Bielstat - Średnie wynagrodzenia, 2021). Niemniej jednak duża część Białorusinów zatrudnionych w przedsiębiorstwach państwowych otrzymuje pensje wielkości 350-370 USD (Belorusskie rabochie, 2020). We wrześniu i październiku 2020 roku średnie wynagrodzenie na Białorusi spadło poniżej 500 USD (Bielstat - Średnie wynagrodzenia, 2021). Spadek wynagrodzeń odczuwalny jest jeszcze bardziej z powodu szybko rosnącej inflacji - na koniec 2020 roku Białoruś odnotowała najwyższą stopę inflacji w ciągu ostatnich czterech lat $-7,4 \%$. Największy wzrost cen w 2020 roku nastąpił w sektorze usług $(8,4 \%)$ oraz w sektorze produktów nieżywnościowych $(8,1 \%)$ (Bank Narodowy Białorusi, 2021). Na fali rosnącej inflacji, która w lutym 2021 roku wyniosła 8,7\% (Bank Narodowy Białorusi, 2021), rząd zdecydował się wzmocnić ręczne sterowanie gospodarką - wprowadził ograniczenia cenowe na niektóre dobra podstawowe oraz leki. W sumie zamrożone zostały ceny na 62 towary o dużej wadze dla społeczeństwa, głównie artykuły spożywcze.

\section{WNIOSKI}

Bezpieczeństwo ekonomiczne Republiki Białoruś jest dziś poważnie zagrożone. Z okresu na okres słabnąca kondycja białoruskiej gospodarki jest pochodną redukcji rosyjskich subsydiów energetycznych, wyczerpywaniem się dotychczasowego modelu gospodarczego opartego głównie na centralnym planowaniu, spadku wiarygodności kredytowej i inwestycyjnej państwa na arenie międzynarodowej, spadku poziomu inwestycji oraz wymiany handlowej. Białorusini coraz częściej przyglądają się sukcesom gospodarczym krajów bałtyckich czy Polski. Z każdym rokiem pogłębia się różnica w poziomie ich życia w porównaniu z obywatelami państw sąsiednich. Kredyt zaufania do państwa jako organizatora życia gospodarczego został wyczerpany. Wiele 
procesów, jak np. odpływ wykwalifikowanej siły roboczej, staje się faktem nie do powstrzymania.

Można prognozować, że koniec 2021 i następny rok nie przyniesie poprawy poziomu bezpieczeństwa ekonomicznego Republiki Białoruś za sprawą kolejnych pakietów sankcji o charakterze sektorowym nałożonych przez Zachód w okresie wiosna-lato 2021. Nieprzypadkowo od tego okresu białoruski Bielstat przestał publikować część danych ekonomicznych, dotyczących między innymi wymiany handlowej. Sytuację zagrożenia w obrębie bezpieczeństwa ekonomicznego spotęguje ponadto kryzys na granicy polsko-białoruskiej i jego konsekwencje. Poważne problemy gospodarcze Białorusi przełożą się na konieczność pogłębionej współpracy z Federacją Rosyjską w ramach Państwa Związkowego oraz spowodują wzrost uzależnienia gospodarczego Mińska od Moskwy.

\section{BIBLIOGRAFIA}

Bank Narodowy Białorusi (2020), Prjamye inostrannye investicii, Nacional'nyj Bank Respubliki Belarus', https://www.nbrb.by/statistics/foreigndirectinvestments [dostęp: 29.10.2021].

Bank Narodowy Białorusi (2021), Obzor infljacii, Nacional'nyj Bank Respubliki Belarus', https://www.nbrb.by/mp/inflation/month [dostęp: 29.10.2021].

Belorusskie rabochie raskryli svoi zarplaty (2020), https://www.mk.ru/politics/2020/08/18/belorusskierabochie-raskryli-svoi-zarplaty.html [dostęp: 15.10.2021].

Bielstat (2019), Strukturnaja biznes-statistika, https://www.belstat.gov.by/ofitsialnaya-statistika/ realny-sector-ekonomiki/strukturnaja_statistika/biznes-statistika/ [dostęp: 15.10.2021].

Bielstat (2020), Finansovye rezul'taty raboty organizacij, www.belstat.gov.by/ofitsialnaya-statistika/realny-sector-ekonomiki/finansy-organizatsiy/godovye-dannye/ [dostęp: 15.10.2021].

Bielstat - Inwestycje Zagraniczne (2021), Inostrannye investicii, https://www.belstat.gov.by/ ofitsialnaya-statistika/realny-sector-ekonomiki/inostrannye-investitsii/ [dostęp: 15.10.2021].

Bielstat - Średnie wynagrodzenia (2021), O nachislennoj srednej zarabotnoj plate rabotnikov Respubliki Belarus' v janvare 2021 g., https://www.belstat.gov.by/ofitsialnaya-statistika/realny-sectorekonomiki/stoimost-rabochey-sily/operativnye-dannye/o-nachislennoy-sredney-zarabotnoy-platerabotnikov/o-nachislennoy-sredney-zarabotnoy-plate-rabotnikov-respubliki-belarus-v-yanvare-2021-g/ [dostęp: 15.10.2021].

Buzan B. (1991), People, States, and Fear: The National Security Problem in International Relations, Brighton: Wheatsheaf Books Ltd.

Czachor R., (2011), Polityka wielowektorowości Republiki Białoruś - geneza, podstawy konceptualne, przyktady realizacji, Wrocławski Przegląd Międzynarodowy, nr 1, s. 53-73.

Czwołek A. (2014), Białorusko-chińska wspótpraca energetyczna: szansa na modernizacje białoruskiego systemu energetycznego, czy gra pozorów?, [w:] J. Marszałek-Kawa, R. Gawłowski (red.), W kierunku nowego ładu gospodarczego - rola Azji w XXI wieku, Toruń: Adam Marszałek, s. 298-329.

Doing Business (2020), Economy Profile Belarus, World Bank Group, https://www.doingbusiness.org/ content/dam/doingBusiness/country/b/belarus/BLR.pdf [dostęp: 12.10.2021]. 
Dolgi belorusskih predprijatij pobili istoricheskij rekord (2021), https://banki24.by/news/4643dolgi-belorusskih-predpriyatiy-pobili [dostęp: 12.10.2021].

Dyner A. M. (2020), Gospodarcze wyzwania dla Biatorusi, Biuletyn PISM, nr 59, 30.03, https://pism.pl/publikacje/Gospodarcze_wyzwania_dla_Bialorusi [dostęp: 12.10.2021].

Dyner A. M. (2021), Rosyjsko-białoruskie porozumienia w sprawie cen węglowodorów, Komentarz PISM, nr 2, https://pism.pl/publikacje/Rosyjskobialoruskie_porozumienia __w_sprawie_cen_ weglowodorow [dostęp: 12.10.2021].

Dyner A. M. (2018), Znaczenie wspótpracy z Chinami dla Białorusi, Biuletyn PISM, nr 106, https://pism.pl/publikacje/Znaczenie_wsp_pracy_z_Chinami_dla_Bia_orusi [dostęp: 12.10.2021].

Fitch (2020), Fitch Ratings: Belarus, https://www.fitchratings.com/research/sovereigns/belarusrating-action-report-13-11-2020 [dostęp: 03.09.2021].

Frejtag-Mika E., Kołodziejak Z., Putkiewicz W. (1996), Bezpieczeństwo ekonomiczne we wspótczesnym świecie, Radom: Wydawnictwo Politechniki Radomskiej.

Gromadzki G., Konończuk W. (2007), Energetyczna gra. Ukraina, Mołdawia i Białoruś między Unia i Rosja, Warszawa: Fundacja im. Stefana Batorego, https://www.batory.org.pl/doc/energetyczna_ gra_pl.pdf [dostęp: 03.09.2021].

Itogi vneshnej torgovli Respubliki Belarus' za janvar'-dekabr' 2020 goda (2021), Tamozhennye Organy Resubliki Belarus', https://www.gtk.gov.by/ru/2020_stat-ru/view/itogi-vneshnej-torgovlirespubliki-belarus-za-janvar-dekabr-2020-goda-16514/ [dostęp: 03.09.2021].

Jakóbowski J., Kłysiński K. (2021), Partnerstwo niestrategiczne. Stosunki białorusko-chińskie, Prace OSW, nr 81, Warszawa: OSW, https://www.osw.waw.pl/sites/default/files/Prace-OSW_ Partnerstwo-niestrategiczne_net_1.pdf [dostęp: 03.09.2021].

Jushkevich S. (2019), Krutoj: Dolja IT-sektora v Belarusi mozhet sostavit' 10\% ot VVP, http://www.belmarket.by/krutoy-dolya-it-sektora-v-belarusi-mozhet-sostavit-10-ot-vvp [dostęp: 25.10.2021].

Kardaś S., Kłysiński K. (2017), Historia bez zakończenia. Nowa odstona rosyjsko-białoruskiego sporu energetycznego, Warszawa: OSW, https://www.osw.waw.pl/pl/publikacje/komentarze-osw/ 2017-05-17/historia-bez-zakonczenia-nowa-odslona-rosyjsko-bialoruskiego [dostęp: 26.10.2021].

Kłysiński K. (2020), Walka reżimu o przetrwanie: 100 dni kryzysu politycznego na Białorusi, Komentarze OSW, nr 336, https://www.osw.waw.pl/pl/publikacje/komentarze-osw/2020-11-27/walkarezimu-o-przetrwanie-100-dni-kryzysu-politycznego-na [12.10.2021].

Kłysiński K. (2021), Koszt państwa milicyjnego - problemy gospodarcze Białorusi, Komentarze OSW, nr 392, https://www.osw.waw.pl/pl/publikacje/komentarze-osw/2021-05-11/koszt-panstwamilicyjnego-problemy-gospodarcze-bialorusi [dostęp: 12.10.2021].

Kłysiński K., Hyndle-Hussein J., Kardaś S. (2020), Inauguracja Elektrowni Jądrowej w Ostrowcu, Analizy OSW, https://www.osw.waw.pl/pl/publikacje/analizy/2020-11-10/inauguracja-bialoruskiejelektrowni-jadrowej-w-ostrowcu [dostęp: 12.10.2021].

Koncepcija nacional'noj bezopasnosti Respubliki Belarus' (2010), Ukaz Prezidenta Respubliki Belarus', 09.11.2010 g., № 575, https://prokuratura.gov.by/ru/acts/kontseptsiya-natsionalnoybezopasnosti-respubliki-belarus/ [dostęp: 12.10.2021].

Kosiedowski W. (2013), Gospodarka białoruska w trakcie przemian. Makroekonomiczny aspekt reform, [w:] R. Łoś, J. Reginii-Zacharski (red.), Sąsiedztwo i pogranicze - między konfliktem a wspótpraca, t. 2, Łódź:Wydawnictwo Uniwersytetu Łódzkiego, s. 221-248. 
Kostecki J. (2016), Wptyw czynników zewnętrznych i wewnętrznych na bezpieczeństwo ekonomiczne Polski, Kwartalnik Naukowy Uczelni Vistula, 3(49), s. 53-80.

Lorot P. (2009), De la géopolitique à la géoéconomie, Geoeconomie, $\mathrm{nr}$ 3(50), pp. 9-19.

Mjasnikovich M. V. (2006), Nacional'naja bezopasnost' Respubliki Belarus': prioritetnye napravlenija social'no-jekonomicheskogo ustojchivogo innovacionnogo razvitija, Minsk: Izdatel'skij dom "Belorusskaja nauka".

MFRB (2020), Sostojanie gosudarstvennogo dolga Respubliki Belarus', http://www.minfin. gov. by/ru/public_debt/condition/ [dostęp: 10.10.2021].

MFW (2018), Respublika Belarus'. Doklad personala dlja konsul'tacij 2018 goda v sootvetstvii so stat'ej IV, s. 4, https://www.imf.org/ /media/Files/Publications/CR/2019/Russian/cr1909r.ashx [dostęp: 10.10.2021].

Mozhejko A. (2021), Jekonomicheskaja bezopasnost'Respubliki Belarus', Bankovskij shestnik, s. 44-53, https://www.nbrb.by/bv/articles/10866.pdf [dostęp: 10.10.2021].

Nacional'naja strategija ustojchivogo social'no-jekonomicheskogo razvitija Respubliki Belarus' na period do 2020 goda (2004), Minsk, s. 14, https://www.minpriroda.gov.by/ru/nsur2020-ru/ [dostęp: 09.09.2021].

Nesadurai H. (2005), Conceptualising Economic Security in an Era of Globalisation: What Does the East Asian Experience Reveal?, CSGR Working Paper, No 157/05, s. 1-26.

Nikitenko P. G. (2009), Jekonomicheskaja bezopasnost': teorija, metodologija, praktika, Minsk: Pravo i jekonomika.

Obywatele Biatorusi w Polsce - raport (2021), Urząd do Spraw Cudzoziemców, https://www. gov.pl/web/udsc/obywatele-bialorusi-w-polsce--raport [dostęp: 10.10.2021].

Osnovnye polozhenija proekta programmy social'no-jekonomicheskogo razvitija Respubliki Belarus' na 2021-2025 gody, http://economy.gov.by/uploads/files/macro-prognoz/Osnovnye-polozhenijaproekta-PSER-na-2021-2025.pdf [dostęp: 10.10.2021].

Raczkowski K. (2012), Percepcja bezpieczeństwa ekonomicznego i wyzwania dla zarzadzania nim w XXI w., [w:] K. Raczkowski (red.), Bezpieczeństwo ekonomiczne. Wyzwania dla zarzqdzania państwem, Warszawa: Wolters Kluwer, s. 69-148.

Romanczuk J. (2017), Poiski luchshej doli. Skol'ko gosudarstva dolzhno byt'v jekonomike strany?, https://bramaby.com/ls/blog/bel/6074.html [dostęp: 23.10.2021].

Rezervy uzhestochenija trudovyh otnoshenij gosudarstvom fakticheski ischerpany (2016), https://belarusinfocus.info/by/regiyony/rezervy-uzhestocheniya-trudovyh-otnosheniy-gosudarstvomfakticheski-ischerpany [dostęp: 23.10.2021].

Respublika Belarus' v zerkale sociologii (2018), Informacionno-analiticheskij centr pri Administracii Prezidenta Respubliki Belarus', Minsk, s. 80, http://eschool.by/wp-content/uploads/2019/04/011.pdf [dostęp: 23.10.2021].

Sel'skoe hozjajstvo Respubliki Belarus', Statisticheskij sbornik (2019), Minsk: Nacional'nyj statisticheskij Komitet Respubliki Belarus' https://belstat.gov.by/upload/iblock/cd8/cd8827937d1460 2dc05d3c32081c0b47.pdf [dostęp 12.10.2021].

Sektor energetyczny Białorusi (2015), Centrum Informacji o Rynku Energii, https://www.cire.pl/ artykuly/materialy-problemowe/105412-sektor-energetyczny-bialorusi [dostęp 12.10.2021].

Senchagov V. (2002), Jekonomicheskaja bezopasnost', geopolitika, globalizacija, samosohranenie i razvitie, Moskva: Finstatinform. 
Soglashenie mezhdu pravitel'stvom Respubliki Belarus' i pravitel'stvom Rossijskoj Federacii o sotrudnichestve v stroitel'stve na territorii Respubliki Belarus' atomnoj jelektrostancii (2011), Minsk, http://sosny.bas-net.by/wp-content/blogs.dir/2/files/2013/05/agreement_2.pdf_[dostęp 12.10.2021].

S\&P (2020), S\&P cuts Belarus Outlook on Heightened Risks Following Presudential Election, S\&P Global, https://www.spglobal.com/marketintelligence/en/news-insights/latest-news-headlines/ s-p-cuts-belarus-outlook-on-heightened-risks-following-presidential-election-60309979 [dostęp: 23.08.2021].

Szubrycht T. (2006), Wspótczesne aspekty bezpieczeństwa państwa, Zeszyty Naukowe Akademii Marynarki Wojennej, nr 4 (167), s. 91-93.

Tambovcev V. L. (1995), Jekonomicheskaja bezopasnost' hozjajstvennyh sistem: struktura i problemy, Vestnik MGU, Serija 6, №3, s. 3-9.

The Heritage Foundation (2021), Index of Economic Freedom, https://www.heritage.org/index/ country/belarus [dostęp: 12.10.2021].

Titova Ju. (2020), Skol'ko Rossija zaplatila za druzhbu s Lukashenko za poslednie 10 let, Forbes, https://www.forbes.ru/finansy-i-investicii/407435-skolko-rossiya-zaplatila-za-druzhbu-s-lukashenkoza-poslednie-10-let [dostęp: 12.10.2021].

Trusewicz I. (2020), W walce o białoruskie firmy II chce nas ubiec Litwa. Mamy jednak asa, https://cyfrowa.rp.pl/globalne-interesy/art18031921-w-walce-o-bialoruskie-firmy-it-chce-nasubiec-litwa-mamy-jednak-asa [dostęp: 28.10.2020].

World Bank (2021), The World Bank in Belarus, https://www.worldbank.org/en/country/belarus/ overview [dostęp: 20.09.2021].

Vedomosti (2020), Vsemirnyj bank raskryl dolgi drugih stran pered Rossiej, https://www.vedomosti. ru/economics/news/2021/03/31/863898-vsemirnii-bank-raskril-dolgi-drugih-stran-pered-rossiei [dostęp: 20.09.2021].

Zajac D. (2021), Belarus' prevrashhaetsja v mertvuju zonu dlja inostrannyh investorov, https://naviny. online/article/20210215/1613367656-belarus-prevrashchaetsya-v-mertvuyu-zonu-dlya-inostrannyhinvestorov [dostęp: 09.10.2021].

\section{BEZPIECZEŃSTWO EKONOMICZNE REPUBLIKI BIAŁORUŚ W DOBIE KRYZYSU POLITYCZNO-GOSPODARCZEGO LAT 2020-POŁOWA 2021}

\section{Streszczenie}

Trzecią dekadę XXI wieku Republika Białoruś rozpoczyna z licznymi problemami, do których przede wszystkim należy zaliczyć niestabilną sytuacją społeczno-polityczną, zerwanie dialogu $\mathrm{z}$ otoczeniem międzynarodowym oraz sankcje Zachodu. Wszystkie wymienione czynniki spowodowały wiele zawirowań w białoruskiej gospodarce. Niniejszy artykuł stanowi próbę zbadania bezpieczeństwa ekonomicznego Republiki Białoruś na tle wyczerpywania się dotychczasowego modelu gospodarki, redukcji rosyjskich subsydiów energetycznych, pandemii Covid-19 i kryzysu politycznego, będącego konsekwencją sfałszowanych wyborów prezydenckich w sierpniu 2020 roku. W charakterze materiałów źródłowych wykorzystane zostały dane pochodzące z białoruskiej bazy Bielstatu, Narodowego Banku Republiki Białoruskiej, Banku Światowego, Międzynarodowego Funduszu Walutowego, a także agencji ratingowych.

Słowa kluczowe: Republika Białoruś; bezpieczeństwo ekonomiczne; gospodarka; kryzys; sankcje. 


\section{ECONOMIC SECURITY OF THE REPUBLIC OF BELARUS \\ DURING THE POLITICAL AND ECONOMIC CRISIS \\ OF 2020-MID-2021}

\section{Summary}

Republic of Belarus begins the third decade of the 21 st century with numerous problems, which include the unstable socio-political situation, broken dialogue and relations with the international environment, and Western sanctions. All these factors have caused a lot of turbulence in the Belarusian economy. This article is an attempt to examine the economic security of Belarus in the period of the depletion of the current economic model, the reduction of Russian energy subsidies, the Covid-19 pandemic and the political crisis resulting from the rigged presidential elections in August 2020. Data from the Belarusian Bielstat database, the National Bank of the Republic of Belarus, the World Bank, the International Monetary Fund, and rating agencies will be used as source materials.

Keywords: Republic of Belarus; economic security; economy; crisis; sanctions. 